\title{
Gasification of coal, Chenopodium Album biomass, and co- gasification of a coal-biomass mixture by thermogravimetric-gas analysis
}

\author{
Marco Antonio Ardila-Barragán ${ }^{1}$ \\ Carlos Francisco Valdés-Rentería ${ }^{2}$ \\ Brennan Pecha ${ }^{3}$ \\ Alfonso López-Díaz ${ }^{4}$ \\ Eduardo Gil-Lancheros ${ }^{5}$ \\ Marley Cecilia Vanegas-Chamorro ${ }^{6}$ \\ Jesús Emilio Camporredondo-Saucedo ${ }^{7}$ \\ Luis Fernando Lozano-Gómez ${ }^{8}$
}

Fecha de recepción: 11 de mayo de 2019

Fecha de aprobación: 25 de septiembre de 2019

\begin{abstract}
Gasification studies were performed on sub-bituminous coal of the province Centro in Boyacá state of Colombia, vegetable biomass Chenopodium album (cenizo) and cogasification of coal-biomass mixtures agglomerated with paraffin in a thermogravimetric analyzer. Biomass synergistically promoted thermochemical transformation of the coal was observed. Experimental results were compared to equilibrium composition simulations. Ash fusibility tests of the coal-biomass mixture were carried out, which allowed to clarify its behavior, such as dry or fluid ash according to own chemical composition, during the gasification process. The experimental tests allowed determining the differences in thermal
\end{abstract}

\footnotetext{
1 Ph.D. (c) Universidad Pedagógica y Tecnológica de Colombia (Tunja-Boyacá, Colombia). marco.ardila@uptc.edu.co. ORCID: 0000-0002-0251-7527.

2 Ph.D. Universidad Nacional de Colombia (Medellín-Antioquia, Colombia). cfvaldes@unal.edu.co. ORCID: 0000-0001-6836-7085.

3 Ph.D. National Renewable Energy Laboratory (Washington, Estados Unidos). brennan.pecha@nrel.gov. ORCID: 0000-0002-0894-8504.

4 Ph.D. Universidad Pedagógica y Tecnológica de Colombia (Tunja-Boyacá, Colombia). alfonso.lopez@uptc.edu.co. ORCID: 0000-0002-2983-7352.

${ }^{5}$ M.Sc. CARBOING S.A.S. (Bogotá-Distrito Capital, Colombia). eduardogil.proyectos@carboing.com. ORCID: 0000-0002-1840-5845.

${ }^{6}$ Ph.D. Universidad del Atlántico (Barranquilla-Atlántico, Colombia). ORCID: 0000-0002-0513-7554.

7 Ph.D. Universidad Autónoma de Coahuila (Monclova-Coahuila, México). ORCID: 0000-0003-2891-355X.

8 M.Sc. Universidad Pedagógica y Tecnológica de Colombia (Tunja-Boyacá, Colombia). luis.lozano@uptc.edu.co. ORCID: 0000-0003-2683-5594.
}

Revista Facultad de Ingeniería (Rev. Fac. Ing.) Vol. 28 (53), pp. 53-77. Octubre-Diciembre 2019.

Tunja-Boyacá, Colombia. L-ISSN: 0121-1129, e-ISSN: 2357-5328, DOI:

https://doi.org/10.19053/01211129.v28.n53.2019.10147 
decomposition, between coal, cenizo and coal-biomass blend, which are attributable to the physicochemical properties of each one solid fuel. During the tests, gas chromatography analyses were performed to establish the compositions of the syngas. The syngas obtained from biomass had the highest concentration of $\mathrm{CO}$ and the lowest $\mathrm{H}_{2}$; the coal and the coalbiomass mixture were slightly minor respectively. Concentrations of $\mathrm{CH}_{4}, \mathrm{CO}_{2}$ and $\mathrm{C}_{2} \mathrm{H}_{4}$ were similar between coal and biomass. This result is consistent with the higher calorific value of the coal syngas. The production of syngas from the coal-biomass mixture had the lowest contents of $\mathrm{H}_{2}$ and $\mathrm{CO}$ due to synergistic phenomena that occur with the fuel mixture. The co-gasification of the mixture gave the highest syngas production, carbon conversion, and thermal efficiency. These results indicate the viability of co-gasification of coalChenopodium album agglomerated mixtures. In gasification of non-agglomerated mixtures of coal-cenizo, the biomass can be burned directly without producing syngas.

Keywords: agglomerated mixtures; chenopodium album; coal-biomass; co-gasification; synergy; syngas.

\section{Gasificación de carbón, biomasa de Chenopodium album, y cogasificación de una mezcla de carbón y biomasa mediante análisis termogavimétrico de gases}

\section{Resumen}

Se llevaron a cabo estudios de gasificación con carbón subituminoso de la provincia Centro del departamento de Boyacá (Colombia), biomasa vegetal de Chenopodium album (cenizo) y de cogasificación de mezclas de carbón-biomasa, aglomerada con parafina en un analizador termogravimétrico. Se observó que la biomasa promovió sinergéticamente la transformación termoquímica del carbón. Los resultados experimentales fueron comparados con simulaciones de la composición de equilibrio. Se realizaron pruebas de fusibilidad de cenizas de la mezcla carbón-biomasa, que permitieron determinar si se comportarían como cenizas secas o fluidas durante el proceso de gasificación, de acuerdo con la composición química. A partir de la experimentación fue posible establecer diferencias entre la descomposición térmica del carbón, el cenizo y la mezcla de carbónbiomasa, las cuales son atribuibles a las propiedades fisicoquímicas de cada combustible sólido. Para precisar la composición del syngas producido durante las pruebas, se hicieron análisis de cromatografía de gases. El syngas obtenido a partir de la biomasa tuvo la concentración más alta de $\mathrm{CO}$ y la más baja de $\mathrm{H}_{2}$; el carbón y la mezcla carbón-biomasa tuvieron concentraciones ligeramente menores. Las concentraciones de $\mathrm{CH}_{4}, \mathrm{CO}_{2}$ y $\mathrm{C}_{2} \mathrm{H}_{4}$ 
Marco Antonio Ardila-Barragán, Carlos Francisco Valdés-Rentería, Brennan Pecha, Alfonso López-Díaz,

Eduardo Gil-Lancheros, Marley Cecilia Vanegas-Chamorro, Jesús Emilio Camporredondo-Saucedo, Luis

Fernando Lozano-Gómez fueron similares entre el carbón y la biomasa. Este resultado es consistente con el valor calorífico alto del syngas obtenido a partir del carbón. La producción del syngas de la mezcla carbón-biomasa presentó los valores más bajos en los contenidos de $\mathrm{H}_{2}$ y $\mathrm{CO}$, debido al fenómeno sinergético que ocurre con la mezcla del combustible. La cogasificación de la mezcla carbón-biomasa dio la mayor producción de gas, de eficiencia en la conversión de carbón y de eficiencia térmica. Estos resultados indican la viabilidad del proceso de cogasificación de mezclas aglomeradas de carbón con Chenopodium album. En gasificación de mezclas no aglomeradas de carbón-cenizo, la biomasa puede quemarse directamente sin producir syngas.

Palabras clave: carbón-biomasa; chenopodium álbum; cogasificación; gas de síntesis; mezclas aglomeradas; sinergia.

\section{Gaseificação de carvão, biomassa de Chenopodium album, e cogaseificação de uma mistura de carvão e biomassa mediante análise termogravimétrico de gases}

\section{Resumo}

Realizaram-se estudos de gaseificação com carvão sub-betuminoso da província Centro do departamento de Boyacá (Colômbia), biomassa vegetal de Chenopodium album (caçador) e de cogaseificação de misturas de carvão-biomassa, aglomerada com parafina em um analisador termogravimétrico. Observou-se que a biomassa promoveu sinergeticamente a transformação termoquímica do carvão. Os resultados experimentais foram comparados com simulações da composição de equilíbrio. Realizaram provas de fusibilidade de cinzas da mistura carvão-biomassa, que permitiram determinar se comportar-se-iam como cinzas secas ou fluídas durante o processo de gaseificação, de acordo com a composição química. A partir da experimentação foi possível estabelecer diferenças entre a decomposição térmica do carvão, o caçador e a mistura de carvãobiomassa, as quais são atribuíveis às propriedades físico-químicas de cada combustível sólido. Para precisar a composição do syngas produzido durante as provas, realizaram-se análises de cromatografia de gases. O syngas obtido a partir da biomassa teve a concentração mais alta de $\mathrm{CO}$ e a mais baixa de $\mathrm{H}_{2}$; o carvão e a mistura carvão-biomassa tiveram concentrações ligeiramente menores. As concentrações de $\mathrm{CH}_{4}, \mathrm{CO}_{2}$ e $\mathrm{C}_{2} \mathrm{H}_{4}$ foram similares entre o carvão e a biomassa. Este resultado é consistente com o valor calorífico alto do syngas obtido a partir do carvão. A produção do syngas da mistura carvão-biomassa apresentou os valores mais baixos nos conteúdos de $\mathrm{H}_{2}$ e $\mathrm{CO}$, devido ao fenômeno 
sinergético que ocorre com a mistura do combustível. A cogaseificação da mistura carvãobiomassa deu a maior produção de gás, de eficiência na conversão de carvão e de eficiência térmica. Estes resultados indicam a viabilidade do processo de cogaseificação de misturas aglomeradas de carvão com Chenopodium album. Em gaseificação de misturas não aglomeradas de carvão-caçador, a biomassa pode queimar-se diretamente sem produzir syngas.

Palavras chave: carvão-biomassa; Chenopodium album; cogaseificação; gás de síntese; misturas aglomeradas; sinergia.

\section{Para citar este artículo:}

M. A. Ardila-Barragán, C. F. Valdés-Rentería, B. Pecha, A. López-Díaz, E. Gil-Lancheros M. C. Vanegas-Chamorro, J. E. Camporredondo-Saucedo, and L. F. Lozano-Gómez, "Gasification of coal, Chenopodium Album biomass, and co-gasification of a coal-biomass mixture by thermogravimetric-gas analysis," Revista Facultad de Ingeniería, vol. 28 (53), pp. 53-77, Oct. 2019. https://doi.org/10.19053/01211129.v28.n53.2019.10147.

Esta obra está bajo licencia internacional Creative Commons Reconocimiento 4.0

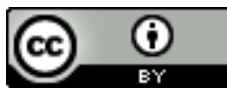


Marco Antonio Ardila-Barragán, Carlos Francisco Valdés-Rentería, Brennan Pecha, Alfonso López-Díaz,

Eduardo Gil-Lancheros, Marley Cecilia Vanegas-Chamorro, Jesús Emilio Camporredondo-Saucedo, Luis

\section{INTRODUCTION}

Fernando Lozano-Gómez

All fuels, except pure hydrogen, produce $\mathrm{NOx}, \mathrm{SOx}, \mathrm{CO}_{2}$, and other pollutants during combustion, whose impacts on environmental sustainability and public health remain a worldwide persistent problem [1]. To combat this, Colombia recently signed a commitment to reduce $\mathrm{CO}_{2}$ emissions by $20 \%$ and implement strategies to optimize energy efficiency, technology transfer, and fuel substitution with renewable resources [2]. Biomass and biomass blended with fossil fuels are feasible substitutes for thermal generation with existing combustion systems. Biomass $\mathrm{CO}_{2}$ emissions are considered nearly neutral through the carbon cycle [3-5] and can greatly reduce environmental impact compared with coal $[6,7]$. One promising pathway for utilizing biomass is to produce syngas through gasification [8-10]. As reviewed by EmamiTaba et al. [11], many studies have found that co-gasification technologies with blends of coal and biomass can greatly enhance the quality and composition of syngas. Chenopodium album, sometimes called lambsquarters, pigweed, melde, goosefoot or fat hen, is an herbaceous biomass classified as a weedy undergrowth that competes with food crops for water, sunlight, space, and soil nutrients [12]. This biomass has the potential to replace wood for co-gasification, whose cultivation cycle requires 15 to 20 years in specific terrains and climates. Chenopodium album is suitable from 0 to 3600 meters above sea level in latitudes from $70^{\circ} \mathrm{N}$ to over $50^{\circ} \mathrm{S}$. It is also tolerant of a wide range of cultivating conditions, climates, soil fertility, and $\mathrm{pH}[13,14,15]$.

To understand the energy production potential of using Chenopodium album, a process evaluation can be performed. For example, Runsheng et al. [16] determined thermal reaction characteristics in charcoal briquettes with iron ore, analyzing the mass loss and the reaction speed of the samples as a function of temperature by the thermal analysis method [16]. Results showed two significant changes in the conversion of the briquettes: at $450^{\circ} \mathrm{C}$ it is reduced with respect to the coal, while at $1030^{\circ} \mathrm{C}$ the conversion increases. These types of problems can be understood with a Gibbs free energy thermodynamic analysis to confirm the composition and degree of spontaneity of the chemical reactions. Ganesh et al. [17] performed a thermodynamic study of the combined carbon gasification process using the 
Lagrange multiplier method and the Gibbs free energy minimization algorithm. These investigations show that Gibbs energy- minimization can be used to optimize the efficiency of gasification processes, as well as identify advantages of various feed mixtures and reactor operating conditions and configurations. This work presents an experimental analysis of co-gasification of a coal-biomass agglomerated with a paraffin binder under fixed bed reactor conditions compared with gasification of pure coal and pure biomass. The equilibrium compositions of the system are calculated using the Gibbs free energy minimization method. Experiments were performed in a thermogravimetric analyzer with a gas chromatography system to evaluate the efficiency of the process, identify synergistic conditions, and compare gas compositions to model predictions.

\section{Methodology}

\section{A. Fuels}

The fuels used were sub-bituminous coal type A (P1) biomass of Chenopodium album (P2) and coal-biomass mixtures in 3:1 ratio (P3). The characterization of coal, biomass, coal-biomass mixture and paraffin was done according to standard procedures as reported in Table 1.

Table 1. Physicochemical characterization of fuels

\begin{tabular}{|c|c|c|c|c|c|c|c|c|c|c|}
\hline \multirow{2}{*}{ Sample } & \multicolumn{4}{|c|}{ Proximate analysis (wt. \%) } & \multicolumn{5}{c|}{ Ultimate analysis (wt. \%, DAF } & \multirow{2}{*}{$\begin{array}{c}\text { HHV } \\
\text { (cal/g) }\end{array}$} \\
\cline { 2 - 10 } & $\mathbf{M}$ & Ash & VM & FC $^{*}$ & $\mathbf{C}$ & $\mathbf{H}$ & $\mathbf{N}$ & $\mathbf{O}^{*}$ & $\mathbf{S}_{\mathbf{T}}$ & \\
\hline Coal (P1) & 7.32 & 14.86 & 41.07 & 36.75 & 70.44 & 5.49 & 1.60 & 20.14 & 2.32 & 5920.0 \\
\hline Biomass (P2) & 5.50 & 1.48 & 73.63 & 19.39 & 45.61 & 5.59 & 4.43 & 44.06 & 0.31 & 3717.4 \\
\hline $\begin{array}{c}\text { 3:1 Mixture } \\
\text { (P3) }\end{array}$ & 7.20 & 11.72 & 48.00 & 33.08 & 64.69 & 5.54 & 2.43 & 25.67 & 1.67 & 5171.1 \\
\hline Paraffin & - & - & - & & 5.23 & 85.23 & - & 14.77 & - & 10994.0 \\
\hline ASTM method & D3173 & D3174 & D3175 & b.d. & \multicolumn{3}{c|}{ D5373 } & b.d. & D3177 & D5865 \\
\hline
\end{tabular}

M, residual moisture; VM, volatile matter; FC, fixed carbon; $\mathrm{S}_{\mathrm{T}}$, Total sulfur; DAF, Dry Ash Free; HHV: High

Heating Value. *calculated by difference, b.d.

Cellulose and lignin contents in the biomass were determined following Tappi T203Cm99 and T222Os83 standards procedures in a Genesys 10S UV-VIS spectrophotometer. The samples were analyzed in a Panalytical Mini pal 2 and in a SEM-CARL ZEISS EVO/MA10, as shown in Table 2. 
Marco Antonio Ardila-Barragán, Carlos Francisco Valdés-Rentería, Brennan Pecha, Alfonso López-Díaz,

Eduardo Gil-Lancheros, Marley Cecilia Vanegas-Chamorro, Jesús Emilio Camporredondo-Saucedo, Luis

Fernando Lozano-Gómez

Table 2. Specific components of biomass (wt. \%)

\begin{tabular}{|c|c|c|c|c|}
\hline Cellulose & Lignin & $\mathbf{K}$ & $\mathbf{M g}$ & $\mathbf{C a}$ \\
\hline 55.6 & 31.1 & 0.313 & 0.1 & 0.015 \\
\hline
\end{tabular}

\section{B. Experimental procedure}

The fuels were gasified in a thermogravimetric analyzer. The gasification tests were carried out on a Linseis Thermobalance, Model STA PT 1600, with L75/220 furnace, applying temperature ramps of $40{ }^{\circ} \mathrm{C} / \mathrm{min}$, between 25 and $700{ }^{\circ} \mathrm{C}$ in nitrogen atmosphere $(20 \mathrm{ml} / \mathrm{min})$, and of $20^{\circ} \mathrm{C} / \mathrm{min}$ between 700 and $950{ }^{\circ} \mathrm{C}$, injecting 2.0 $\mathrm{ml} / \mathrm{min}$ of air as a gasifying agent, with an air/fuel ratio (ER) of 0.4 ; this condition was maintained at $950{ }^{\circ} \mathrm{C}$ for 40 minutes. For each test, gas samples were analyzed at 750,850 and $950{ }^{\circ} \mathrm{C}$; then one sample every 20 minutes during the isothermal period. All experimental tests were carried out at least twice in each case. In Figure 1 the schematic of assembly of equipment for conducting the tests is presented [18].

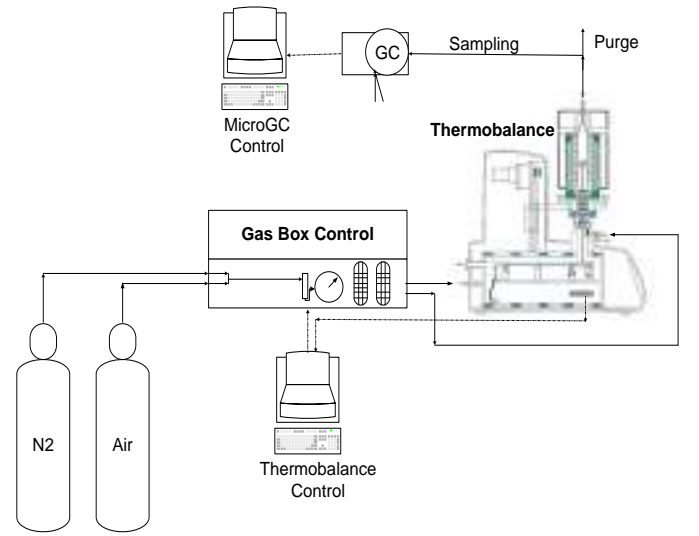

Fig. 1. Schematic of system used for TGA gasification studies.

The composition of the gas products was determined with an Agilent 3000A MicroGC chromatograph, which has two thermal conductivity detectors (TCD) and a $5 \AA$ molecular sieve column with $10 \mathrm{~m} \times 0.32 \mathrm{~mm}$ using $\mathrm{Ar}$ as carrier gas and a Plot $U$ capillary column, with $8 \mathrm{~m} \times 0.32 \mathrm{~mm}$ using He as carrier gas. The analysis method was calibrated under the same operating conditions through standards produced and certified by Praxair-Colombia. The method was used to quantify concentrations 
(vol. \%) of $\mathrm{H}_{2}, \mathrm{O}_{2}, \mathrm{~N}_{2}, \mathrm{CH}_{4}, \mathrm{CO}, \mathrm{CO}_{2}, \mathrm{H}_{2} \mathrm{~S}, \mathrm{C}_{2} \mathrm{H}_{4}, \mathrm{C}_{2} \mathrm{H}_{6}$ and $\mathrm{C}_{3} \mathrm{H}_{8}$. Procedures for interpreting thermogravimetric mass-loss data follow the method developed by Desamparados [19]. The gas samples were cleaned in a system consisting of a gas bubbling device in isopropanol at $0^{\circ} \mathrm{C}$ to capture tar, and a filter with silica gel to remove moisture, before performing the gas chromatographic analysis. The results of the characterization of gases and the process were used to evaluate the performance of the same through parameters such as gas production $\left(\mathrm{Y}_{\mathrm{g}}\right)$, carbon conversion efficiency $\left(E_{c c}\right)$ and thermal efficiency $\left(E_{T h}\right)$, which are determined according to equations $1-4$ [20]:

$$
\begin{gathered}
Y_{g}=\frac{F_{g}-F_{N_{2}}}{F_{f}} \\
F_{g}=\frac{\left(F_{a} * w_{N 2, a}+F_{N 2}+F_{f} * w_{N 2, f}\right)}{w_{N 2, g}} \\
E_{c c}=\frac{F_{g}\left(w_{C O}+w_{C O_{2}}+w_{C H_{4}}+w_{C_{2} H_{4}}\right)}{F_{f} w_{C}\left(1-w_{a s h}\right)} \\
E_{T h}=\frac{F_{g} H H V_{g}}{F_{f} L H V_{f}}
\end{gathered}
$$

Where $F_{g}, F_{f}, F_{a}$, and $F_{N 2}$ are the total gas flow, solid fuel, air flow and drag nitrogen

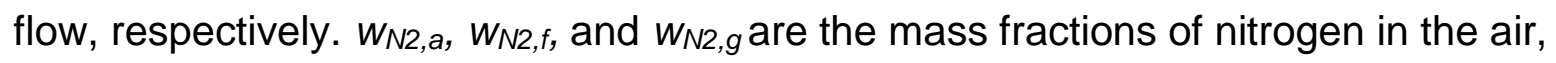
in the fuel and in the gas produced. Carbon conversion efficiency was calculated from Eq.3, where $w_{\mathrm{CO}}, w_{\mathrm{CO}}, w_{\mathrm{CH}}, w_{\mathrm{C}_{2}} 4$ are the mass fractions of $\mathrm{CO}, \mathrm{CO}_{2}, \mathrm{CH}_{4}$, $\mathrm{C}_{2} \mathrm{H}_{4}$ in gas, $w_{C}$ and $w_{a s h}$ are carbon and ash in the fuel, respectively, while the thermal efficiency was calculated according to the $H H V_{g}$ of gas and $L H V_{f}$ of solid fuel. For the previous calculations, it was considered that the moisture content in fuel is extracted during the drying phase [20], nitrogen and air are injected dry to the process; therefore, the incidence of dehydration reactions [18], as well as of evaporation of minerals [21], is considered negligible. Likewise, it is considered that NOx is not produced, because the nitrogen from the biomass leaves as ammonia groups during pyrolysis between 300 and $600{ }^{\circ} \mathrm{C}$; wheareas, the $\mathrm{N}_{2}$ that is in the coal at high temperatures remains strongly linked to structures such as pyrols and quaternary functional groups [22-24], making part of rings of aromatic rings in clusters formed during the graffiti of the carbonaceous structure. 
Marco Antonio Ardila-Barragán, Carlos Francisco Valdés-Rentería, Brennan Pecha, Alfonso López-Díaz,

Eduardo Gil-Lancheros, Marley Cecilia Vanegas-Chamorro, Jesús Emilio Camporredondo-Saucedo, Luis

Fernando Lozano-Gómez

In order to observe the behavior of the paraffin during the drying phase in the gasification test of the agglomerated mixture, analysis of the degradation and expenditure of the binder was carried out. For this, four samples were heated at temperatures of $40,85,100$ and $115{ }^{\circ} \mathrm{C}$ for 12 hours, to make a morphological analysis in a SEM-CARL ZEISS EVO/MA10, under procedures of the ASTM E-3 standard.

Fusible tests of the ashes from the coal-biomass mixture were performed following ASTM D1857 in a CARBOLITE model equipment model CAF-905S, in oxidizing atmosphere, in order to establish if the behavior of the mineral matter present in the sample, during the gasification process, is of solid or fluid ash [10, 25]. The mean fusion temperature (MFT) can also be calculated from the mineralogical composition of the ashes, which were previously analyzed by X-ray diffraction (XRD) [26] to identify qualitatively and quantitatively the crystalline compounds present [27].

\section{Mathematical model}

The equilibrium composition in simple reactions can be determined from the equilibrium constants; however, in the thermodynamic analysis of the gasification process, which is more complex and eventually includes the simultaneous development of multiple chemical reactions, the Gibbs free energy minimization algorithm $(G)$ is used [28]. The equilibrium of a system of chemical reactions at constant temperature and pressure [29] can be expressed by the following equation:

$$
G=\sum_{i=1}^{K_{N}} \mu_{i} n_{i}
$$

If $n_{i}$ satisfies the elemental balance of mass,

$$
\sum_{i=1}^{K_{N}} a_{l i} n_{i}=b_{l}, \quad l=1, \ldots, M
$$

The minimum value of $\mathrm{G}$ is:

$$
G=\sum_{i=1}^{K_{N}} n_{i} \Delta G_{i}^{0}+R T \sum_{i=1}^{K_{N}} n_{i} \ln y_{i}+R T \sum_{i=1}^{K_{N}} n_{i} \ln P
$$

Where: $a_{l i}$, Number of gram atoms of element $l$ in a mass of species $i . b_{l}$, Total number of gram atoms of element $/$ in the reaction mixture. $G$, Gibbs free energy. $K_{N}$, Total number of chemical species in the reaction mixture. $M$, Total number of atomic 
elements. $n_{i}$, Number of moles of species $i . N$, Total number of moles of all species in the gas mixture. $P$, System pressure. $R$, Constant of gases. $T$, Temperature. $y_{i}$, Molar fraction of species i. $\Delta G_{i}^{0}$, Gibbs free energy standard formation of species $i$. $\mu_{i}$, Chemical potential of the species $i$.

\section{Simulation}

The Gibbs free energy minimization algorithm [30] was used to find the equilibrium composition of the chemical reactions of the gasification process. The equilibrium models are based on the assumption that the speed of the particular reactions is infinitely high, or the process time is sufficiently long, which allows the analyzed system to reach the state of equilibrium [31]. The simulation is carried out according to the methodology proposed by De Armas et al., for mathematical modeling and simulation [32]. Commercial software HSC Chemistry for Windows V 6.0., module: Equilibrium compositions were used in this work. The software is loaded with the data of the mass (millimoles) consumed during the gasification process of the samples with air as shown in Table 3, according to the chemical reactions (R1 to $\mathrm{R} 9$ ), to determine the evolution of the equilibrium composition depending on the temperature, within a range of 25 to $950^{\circ} \mathrm{C}$ and an atmosphere of pressure [33].

Table 3. Mass reacted by sample for simulation in HSC

\begin{tabular}{|c|c|c|c|c|c|c|c|c|c|}
\hline \multirow[t]{2}{*}{ Sample } & \multirow{2}{*}{$\begin{array}{c}\text { Initial } \\
\text { weight } \\
\text { (mg) }\end{array}$} & \multirow{2}{*}{$\begin{array}{c}\text { Total } \\
\text { reacted } \\
\text { weight } \\
(\mathrm{mg})\end{array}$} & \multirow{2}{*}{$\begin{array}{c}\text { Reacted } \\
\text { weight } \\
\text { up to } \\
750^{\circ} \mathrm{C} \\
\text { (mg) }\end{array}$} & \multirow{2}{*}{$\begin{array}{c}\text { Reacted } \\
\text { weight } \\
\text { from } \\
750^{\circ} \mathrm{C} \\
(\mathrm{mg})\end{array}$} & \multicolumn{4}{|c|}{$\begin{array}{l}\text { Reacted elements } \\
\text { (mmoles) }\end{array}$} & \multirow{2}{*}{$\begin{array}{c}\begin{array}{c}\text { Hydrogen-Oxygen } \\
\text { Compounds } \\
\text { (mmoles) }\end{array} \\
\mathrm{H}_{2} \mathrm{O}(\mathrm{v}) \\
\end{array}$} \\
\hline & & & & & C & H & S & 0 & \\
\hline P1 & 24.81 & 15.55 & 11.20 & 4.35 & 0.305 & 0.033 & 0.001 & 0.209 & 0.01 \\
\hline $\mathrm{P} 2$ & 23.05 & 19.47 & 15.57 & 3.90 & 0.126 & 0.007 & 0.001 & 0.069 & 0.01 \\
\hline P3 & 24.92 & 15.36 & 13.45 & 1.91 & 0.091 & 0.019 & 0.001 & 0.05 & 0.01 \\
\hline
\end{tabular}

$$
\text { Solid fuel }+ \text { heat }=\text { Dry fuel }+ \text { Steam }
$$

Dry fuel + heat $=$ Volatile matter + Char

$$
\begin{aligned}
& \mathrm{CO}+\frac{1}{2} \mathrm{O}_{2}=\mathrm{CO}_{2} \quad \Delta \mathrm{H}=-283 \frac{\mathrm{kJ}}{\mathrm{mol}} \\
& \mathrm{C}+\mathrm{O}_{2}=\mathrm{CO}_{2} \quad \Delta \mathrm{H}=-393.6 \frac{\mathrm{kJ}}{\mathrm{mol}} \\
& \mathrm{C}+\frac{1}{2} \mathrm{O}_{2}=\mathrm{CO} \quad \Delta \mathrm{H}=-110.6 \frac{\mathrm{kJ}}{\mathrm{mol}}
\end{aligned}
$$


Marco Antonio Ardila-Barragán, Carlos Francisco Valdés-Rentería, Brennan Pecha, Alfonso López-Díaz,

Eduardo Gil-Lancheros, Marley Cecilia Vanegas-Chamorro, Jesús Emilio Camporredondo-Saucedo, Luis

$$
\begin{gathered}
\mathrm{C}+\mathrm{H}_{2} \mathrm{O}=\mathrm{CO}+\mathrm{H}_{2} \quad \Delta \mathrm{H}=131.3 \frac{\mathrm{kJ}}{\mathrm{mol}} \\
\mathrm{C}+2 \mathrm{H}_{2}=\mathrm{CH}_{4} \quad \Delta \mathrm{H}=-74.9 \frac{\mathrm{kJ}}{\mathrm{mol}} \\
\mathrm{CO}+\mathrm{H}_{2} \mathrm{O}=\mathrm{CO}_{2}+\mathrm{H}_{2} \quad \Delta \mathrm{H}=-41.2 \frac{\mathrm{kJ}}{\mathrm{mol}} \\
\mathrm{C}+\mathrm{CO}_{2}=2 \mathrm{CO} \quad \Delta \mathrm{H}=172.5 \frac{\mathrm{kJ}}{\mathrm{mol}}
\end{gathered}
$$

\section{RESULTS AND DISCUSSION}

\section{A. Gasification experimental results}

Gasification of coal (P1), biomass (P2), and the coal-biomass agglomerate (P3) were performed in the TGA. Figure 2 shows the mass loss as a function of temperature and time as well as the derivatives. The TGA curves show four phases, in accord with other published works $[7,11,25,34]$. During the drying phase $(\mathrm{F} 1)$ up to $150{ }^{\circ} \mathrm{C}$ there is loss of water and organic solvents of low molecular weight as well as desorption of gases. In the devolatilization phase (F2) between 150 and $250^{\circ} \mathrm{C}$ low molecular weight organic components, adsorbed water, and paraffin in the coalbiomass agglomerated mixture are released. The drying stage with degassing of $\mathrm{CO}_{2}, \mathrm{CH}_{4}$ and $\mathrm{N}_{2}$ is similar for all samples up to $200{ }^{\circ} \mathrm{C}$, comparable with other studies [18].

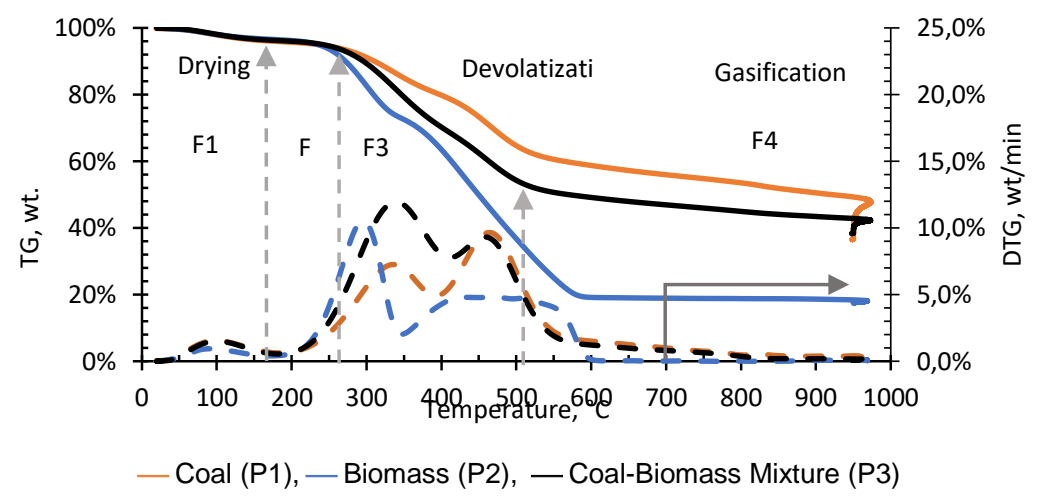

Fig. 2. DTA - DTG curves from gasification experiments.

Between 250 and $500{ }^{\circ} \mathrm{C}(\mathrm{F} 3)$, thermal degradation occurs under $\mathrm{N}_{2}$ which releases organic compounds and some light gases. The highest levels of devolatilization are observed between 200 and $550{ }^{\circ} \mathrm{C}$, with differences between biomass, coal and 
mixture, explained from the composition and compounds present in each of the samples. At temperatures above $500{ }^{\circ} \mathrm{C}$ carbonization of hydrocarbon compounds (F4) occurs, whose pyrolysis does not lead to much further volatile formation [19]. The majority of light gas formation occurs when oxygen is added to the system. In the thermal decomposition curves, it is observed that the mass loss in the coal sample is significantly lower with respect to the biomass sample. This behavior is due to the fact that the biomass is composed of polymeric compounds of cellulose, hemicellulose and lignin which decompose at low temperatures, between 200 and $600{ }^{\circ} \mathrm{C}[35,36]$. The melting phase of coal contains polycyclic aromatic hydrocarbons with higher binding energies and consequently decompose at a higher temperature [37]. The low biomass content in the coal-biomass mixture explains why its mass loss temperatures generally resemble pure coal gasification [7, 34]. However it also shows a synergistic effect that is generated on the process with the addition of biomass, which accelerates the primary devolatilization between 200 and $400^{\circ} \mathrm{C}$; even though the mass loss curves during this stage are similar, the shape and speed of decomposition are different as seen in its DTG (see Fig. 2) compared to that of coal [38]. This phenomenon does not appear to have a significant effect on the later gasification stage. The mass losses verified after the primary devolatilization $\left(550\right.$ and $700^{\circ} \mathrm{C}$ ), are attributable to secondary crosslinking reactions of nascent char and repolymerization of high molecular weight volatiles that reach to be expelled [18, 39, 40].

Air injection at $700{ }^{\circ} \mathrm{C}$ initiates the gasification process. Combustion and partialcombustion reactions ( $\mathrm{R} 4$ and $\mathrm{R} 5$ ), production of hydrogen (R6), production of methane (R7) and production of other synthesis gas compounds obtained from the shift (R8) and Boudouard (R9) reactions occur above $650^{\circ} \mathrm{C}$ [39]. These reactions are reflected in the gradual mass loss shown in Figure 2.

The average composition ( $\% \mathrm{p}$ ) of the gas obtained from P1, P2 and P3, in nitrogenfree and oxygen-free base is shown in Figure 3. Notable contents of $\mathrm{H}_{2} \mathrm{~S}, \mathrm{C}_{2} \mathrm{H}_{4}, \mathrm{C}_{2} \mathrm{H}_{6}$ and $\mathrm{C}_{3} \mathrm{H}_{8}$ were not observed. During the gasification of the samples, hydrogen production is very low and does not show a specific trend; In this case, the coal registers the highest amount of propulsion with very little difference with respect to 
Marco Antonio Ardila-Barragán, Carlos Francisco Valdés-Rentería, Brennan Pecha, Alfonso López-Díaz,

Eduardo Gil-Lancheros, Marley Cecilia Vanegas-Chamorro, Jesús Emilio Camporredondo-Saucedo, Luis Fernando Lozano-Gómez the biomass (1.74\%) and the mixture (1.52). This behavior is likely related to the temperatures reached by the process, elemental composition of biomass, and ash content as discussed later in this work [11].

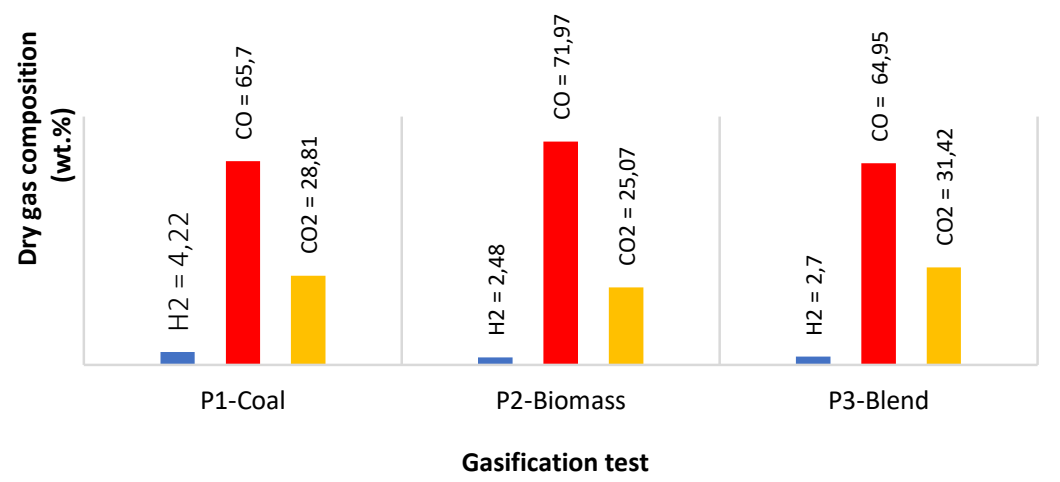

Fig. 3. Gas compositions of the three gasified samples, $\square \mathrm{H}_{2}, \square \mathrm{CO}, \square \mathrm{CO}_{2}$.

The concentration of $\mathrm{CO}$ from the carbon-biomass co-gasification is nearly the same as the gas produced during coal gasification ( $0.75 \%)$; this is likely due to the greater reactivity of the biomass's volatile matter which has high oxygen. The production of $\mathrm{CO}$ in the biomass gasification is $7.02 \%$ higher than in the cogasification of biomasscoal. This is likely due to the abundance of oxygenated groups, the high content of volatiles in the biomass, and possible catalytic effects promoted by some components of the inorganic material present in the ash which can accelerate or inhibit the thermal decomposition of heavy hydrocarbons to form hydrocarbons lighter than methane or ethane $[7,11,42,43]$. $\mathrm{SiO}_{2}$, for example, has been reported as a gasification inhibitor [44, 45].

Methane formation during the devolatilization of samples occurs through demethylation reactions of the aromatic structures (rearrangement) in the carbon and in the lignin of the biomass $[46,47]$. With co-gasification, there is a reduction in the formation of $\mathrm{CH}_{4}$ compared to that obtained for coal and biomass individually. This may be due to the oxidation of the methyl groups formed during the pyrolysis phase with the oxygen released from the biomass, or because with the addition of biomass the presence of aliphatics since devolatilization is lower $[18,48]$. The increase in $\mathrm{CO}_{2}$ is commonly observed in tests with ER equal to 0.4 [46], and the 
presence of oxygen in the biomass [11]. Using air as a gasifying agent does not enhance the concentration of hydrogen since it does not promote the reactions R6 and R8; therefore, the reaction of methanation (R7) becomes irrelevant, but the formation of $\mathrm{CO}_{2}$ is favored [20,41].

At high temperature, the dehydration reactions have little relevance, so the moisture content in the outgoing gas stream is negligible and reactions $\mathrm{R} 6$ and $\mathrm{R} 8$ are not promoted. The nitrogen contained in the samples is released as ammonia compounds during the devolatilization stage, which leads to negligible amounts of NOx formed at high temperature $[50,51]$. The formation of NOx at high temperature due to the air current is negligible in this case. Nitrogen in coal generally exists in heterocyclic aromatic organic structures such as pyrroles, pyridine and quaternary functional groups, which are thermally more stable and are not easily released during gasification $[23,52]$.

The highest gas production ( $\mathrm{Yg}, 76.6 \%$ ) is obtained from the mixture (P3), which is consistent with the investigations reported by Emami-Taba et al. [11]; the differences with respect to coal $(P 1,36.8)$ and biomass $(P 2,42.8)$ are $39.8 \%$ and $33.8 \%$. This behavior is comparable with gasification tests of biomass carbon mixtures, performed with ER of 0.3 and 0.4 in other investigations [20,53], in which it was observed that when the biomass content in the mixture and the ER ratio are higher, production improves [20]. The conversion of carbon (Ecc) improves with the high content of volatile matter that increases the reactivity of the biomass and promotes the formation of free radicals, favoring the reactions of decomposition, oxidation and gasification; in addition, the increase in hydrogen and oxygen contents from biomass make the conversion of carbon during co-gasification is greater than in coal gasification [11]. Based on the previous analysis, the differences found between the results of the coal conversion during the gasification of the samples P1 (44.9\%), P2 (44\%) and P3 (88.7\%) are explained. The HHV of coal syngas is $11.52 \mathrm{MJ} / \mathrm{Nm}^{3}$ while biomass had 11.24 MJ/ $\mathrm{Nm}^{3}$ and the mixture had HHV 11.02. The thermal efficiency $\left(E_{T h}\right)$ of the coal-biomass mixture $(P 3,40.4)$ is 21.4 and 3.7 units higher than in coal $(P 1,19.0)$ and biomass $(P 2,36.7)$, respectively. This suggests that under these experimental conditions, the biomass gas is of lower calorific value than 
Marco Antonio Ardila-Barragán, Carlos Francisco Valdés-Rentería, Brennan Pecha, Alfonso López-Díaz,

Eduardo Gil-Lancheros, Marley Cecilia Vanegas-Chamorro, Jesús Emilio Camporredondo-Saucedo, Luis Fernando Lozano-Gómez coal gas, and promotes the reduction of this property in the mixture gas (P3); this trend can be explained based by Uson et al. [51], where it is described that the high oxygen content in biomass favors the production of carbon dioxide, reducing the formation of hydrogen and carbon monoxide, which are the species that provide the calorific value to the syngas.

Since paraffin was used as a binder, Figure 4 shows the morphological changes in the surface of the sample due to the degradation and consumption of the binder. At $40{ }^{\circ} \mathrm{C}$ (Figure $4 \mathrm{a}$ ) there are solidified paraffin agglomerations, with rounded edges and smooth surface. This indicates that this material was exposed to a heating in which it did not reach the total melting point. At $85^{\circ} \mathrm{C}$ (Fig. 4b), the paraffin has exceeded the melting point and shows a resolidification with texture and irregular agglomerations, suggesting some level of degradation. The micrograph of the sample exposed to $100^{\circ} \mathrm{C}$ (Fig. 4c) shows solid surfaces with the appearance of a very thin coating, but there is no evidence of agglomerations. At $115^{\circ} \mathrm{C}$ the sample (Fig. 4d) shows the surface of the carbon grains with high resolution, where no agglomerations or visible layers of paraffin are detected; it is inferred that under these conditions the paraffin has been degraded and removed together with the water vapor, during the drying phase of the sample, and the remaining binder is dragged in the nitrogen atmosphere during the devolatilization, from $370{ }^{\circ} \mathrm{C}$. Therefore, it is considered that paraffin neither has effects on the gasification process, nor on the mineral species in the fuels.

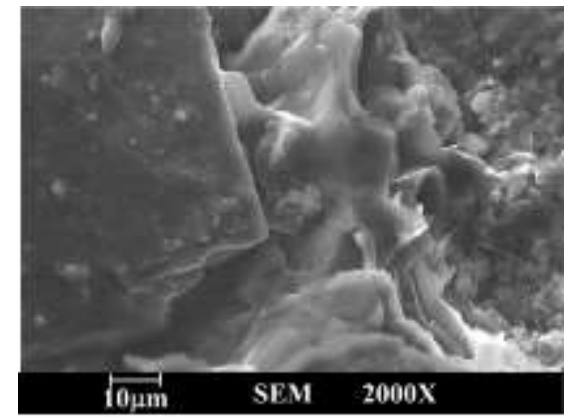

a) Sample heated at $40^{\circ} \mathrm{C}$

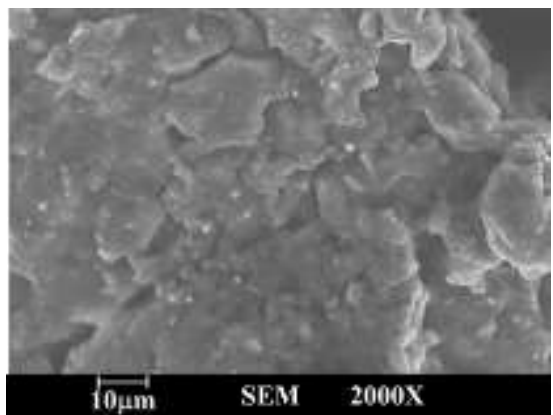

b) Sample heated at $85^{\circ} \mathrm{C}$ 


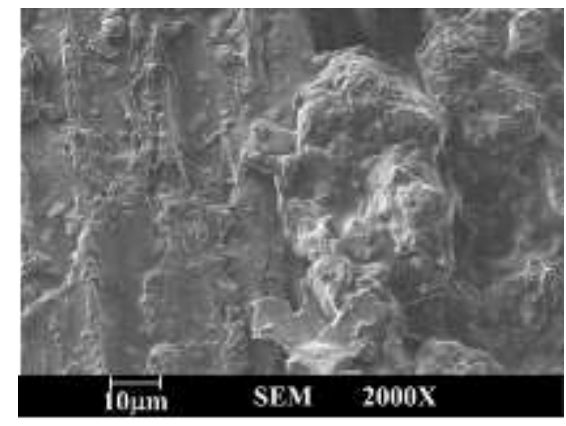

c) Sample heated at $100^{\circ} \mathrm{C}$

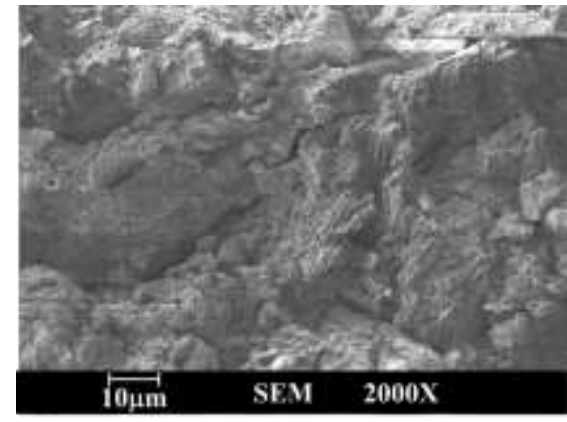

d) Sample heated at $115^{\circ} \mathrm{C}$

Fig. 4. Behavior of the binder in the mixture during heating at different temperatures.

In order to understand the effects of ash, studies to characterize the fusibility of the coal-biomass solids residue were performed. Figure 5 shows the photographic record of the different degrees of deformation of the samples as a function of temperature. A summary of these results in Table 4 shows that all monitored temperatures are lower than the mean fusion temperature -MFT- $\left(1528.78{ }^{\circ} \mathrm{C}\right)$ calculated from ash composition, but also significantly exceed the maximum temperature of the gasification tests $\left(950^{\circ} \mathrm{C}\right)$. The organic matter present in the coal is composed of ash-forming elements such as $\mathrm{Si}, \mathrm{Al}, \mathrm{Fe}, \mathrm{Ca}, \mathrm{Mg}, \mathrm{Na}, \mathrm{K}, \mathrm{Ti}, \mathrm{S}, \mathrm{P}$; trace elements ( $\mathrm{Cl}, \mathrm{F}, \mathrm{Hg}$, As, Se, and $\mathrm{Cr}$ ) that generally increase during processes with carbon; rare elements ( $\mathrm{Ge}, \mathrm{Ga}, \mathrm{U}, \mathrm{Mo}, \mathrm{Be}, \mathrm{Sc}$ ), elements of economic interest (Ag, $\mathrm{Zn}$ and $\mathrm{Ge}$ ), and dangerous elements ( $\mathrm{Cd}$ and $\mathrm{Se}$ ) [52].

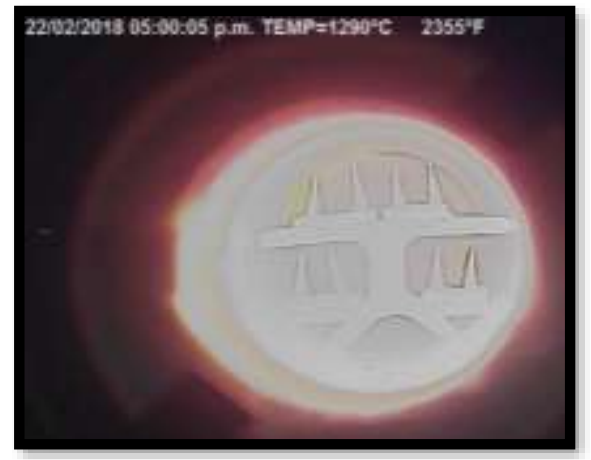

a) Deformation temperature (DT)

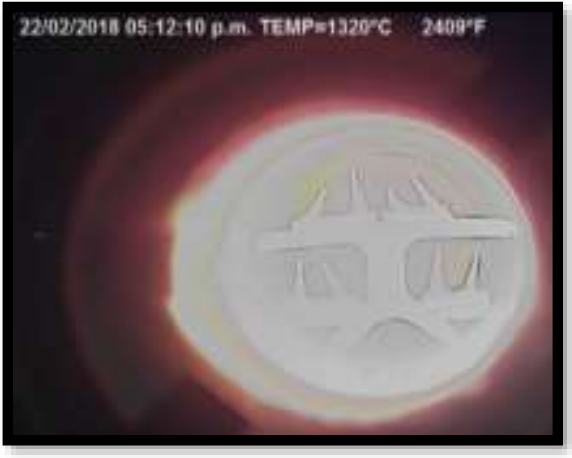

b) Softening Temperature (ST) 
Marco Antonio Ardila-Barragán, Carlos Francisco Valdés-Rentería, Brennan Pecha, Alfonso López-Díaz, Eduardo Gil-Lancheros, Marley Cecilia Vanegas-Chamorro, Jesús Emilio Camporredondo-Saucedo, Luis

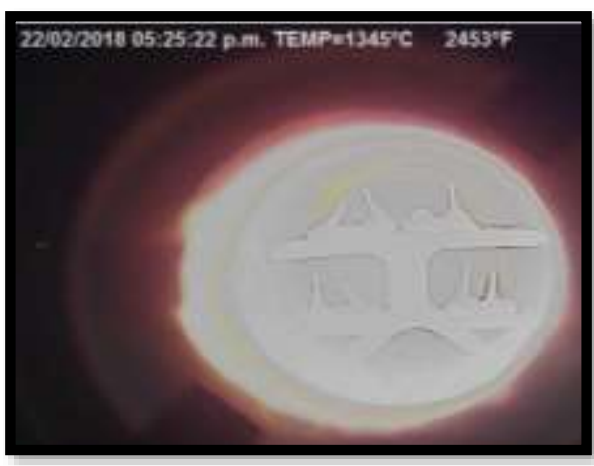

c) Hemispheric Temperature (HT)

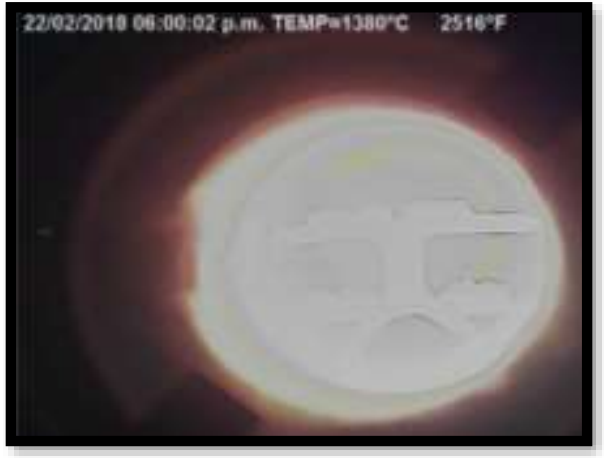

d) Fluency Temperature (FT)

Fig. 5. Ash fusibility imaging results for the coal-biomass mixture.

Table 4. Temperatures of tests of ash fusibility.

\begin{tabular}{|c|c|c|c|c|c|c|c|c|}
\hline \multirow{2}{*}{ Mixture } & \multicolumn{8}{|c|}{ Temperature $\left({ }^{\circ} \mathrm{C}\right)$} \\
\hline & DT & & ST & HT & & FT & & \\
\hline \multirow[t]{3}{*}{ Coal-Biomass } & 1290 & & 1320 & 1345 & & 1380 & & .78 \\
\hline & \multicolumn{8}{|c|}{ Mineralogical composition (wt. \%) } \\
\hline & $\mathrm{Al}_{2} \mathrm{O}_{3}$ & $\mathrm{SiO}_{2}$ & $\mathrm{~K}_{2} \mathrm{O}$ & $\mathrm{Na}_{2} \mathrm{O}$ & $\mathrm{CaO}$ & $\mathrm{Fe}_{2} \mathrm{O}_{3}$ & $\mathrm{MgO}$ & $\mathrm{TiO}_{2}$ \\
\hline Coal-Biomass & 4.53 & 80.29 & 0.77 & 0.18 & 1.13 & 8.55 & 4.51 & 0.04 \\
\hline
\end{tabular}

In other investigations on the behavior of ash fusibility under coal gasification conditions [53], it is found that the presence of $\mathrm{CaCO}_{3}$ and other additives can reduce the hemispheric temperature between 50 and $500 \mathrm{~K}$ and interact with other components within the ternary system $\mathrm{SiO}_{2}-\mathrm{Al}_{2} \mathrm{O}_{3}-\mathrm{CaO}$. This tendency could explain the difference between MFT and HT of the fusibility test, given the contents of calcium, potassium and magnesium that the Chenopodium album provides. It is also observed that FT is smaller than DT; this result is simulated in gas gasification tests with $\mathrm{CO}_{2}$ and $\mathrm{H}_{2} \mathrm{O}$ carried out by Wu [54]. Fusion of the ash starts mainly with ironcontaining minerals, such as the ferrite and wustite phases. The process also may be accelerated by the presence of calcium to form eutectic mixtures in the $\mathrm{FeOsSiO}_{2} \mathrm{SAl}_{2} \mathrm{O}_{3}$ system and $\mathrm{CaOsSiO}_{2} \mathrm{SAl}_{2} \mathrm{O}_{3}$. The fusibility of the main minerals and the mechanism of reaction at the molecular level, of coal ash mixed under gasification conditions, shows that the melting temperature decreases when mullite is transformed into anortite at average temperatures of $1400 \mathrm{~K}$ [55].

The results of the mineralogical composition (Table 4) show $\mathrm{SiO}_{2}$ as the primary species, for which negative inhibitory effects have been reported in the formation of $\mathrm{H}_{2}$ and $\mathrm{CO}_{2}$ on gasification. Upon combustion, depending on the reaction 
environment, the heating rate and the mineralogical composition ( $\mathrm{K}$ and $\mathrm{P}$ ), at temperatures between 700 and $1000{ }^{\circ} \mathrm{C}$, the formation of low melting point salts is possible, which can trap fractions of carbon (sintered), preventing conversion [56], $[60,61]$. However, the presence of $\mathrm{Fe}_{2} \mathrm{O}_{3}, \mathrm{~K}_{2} \mathrm{O}$ and $\mathrm{CaO}$ favor the occurrence of cracking reactions of tars, which can enhance in gas and char formation [41].

\section{B. Simulation of the gasification process in HSC}

As a result of the simulation of the gasification processes of samples P1, P2 and P3, equilibrium composition curves were obtained for $\mathrm{CO}, \mathrm{CO} 2, \mathrm{H} 2, \mathrm{CH} 4, \mathrm{C} 2 \mathrm{H} 4$ y $\mathrm{H} 2 \mathrm{~S}$ and for the temperature range between 750 and $950{ }^{\circ} \mathrm{C}$ (Figures 6 a), b) y c)). Simulated equilibrium composition curves (Simulated) for P1 and P3, are nearly constant above $750{ }^{\circ} \mathrm{C}$. A similar behavior was reported by Żogała [31], applying the stoichiometric method for the modeling of the carbon gasification reactions equilibrium when plotting the logarithm of the constants as a function of temperature. As a result of the simulation of coal (P1), it is observed that simulated $\mathrm{CO}$ and $\mathrm{H}_{2}$ are $5.82 \%$ and $4.62 \%$, higher than those produced experimentally, while simulated $\mathrm{CO}_{2}$ is $10.82 \%$ less than the experimental one; the remaining gases do not show significant differences and the production has zero. The differences among the results of the experimental curves of composition and the simulated curves of the equilibrium composition, for the processes of gasification of biomass (P2) and the mixture P3, present the same trends with very small variations with respect to the values observed in $\mathrm{P} 1$. The reduction in the production of $\mathrm{CO}$ and $\mathrm{H}_{2}$, as well as the increase in the production of $\mathrm{CO}_{2}$, is comparable with the behaviors of experimental investigations $[11,54]$, explained above.
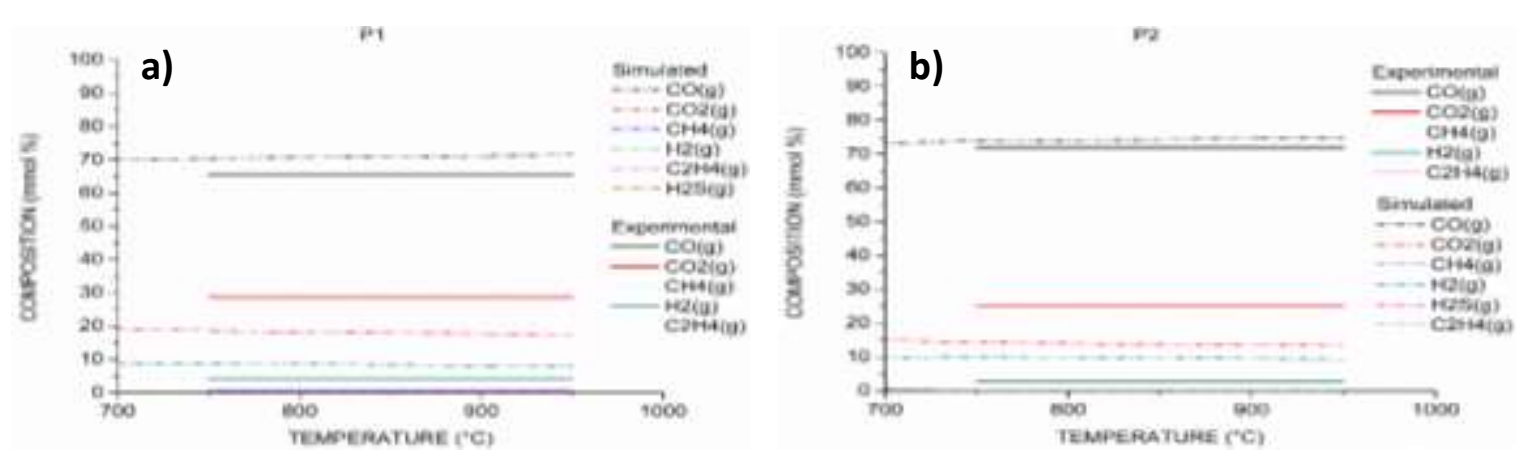

Revista Facultad de Ingeniería (Rev. Fac. Ing.) Vol. 28 (53), pp. 53-77. Octubre-Diciembre 2019.

Tunja-Boyacá, Colombia. L-ISSN: 0121-1129, e-ISSN: 2357-5328, DOI: https://doi.org/10.19053/01211129.v28.n53.2019.10147 
Marco Antonio Ardila-Barragán, Carlos Francisco Valdés-Rentería, Brennan Pecha, Alfonso López-Díaz,

Eduardo Gil-Lancheros, Marley Cecilia Vanegas-Chamorro, Jesús Emilio Camporredondo-Saucedo, Luis Fernando Lozano-Gómez

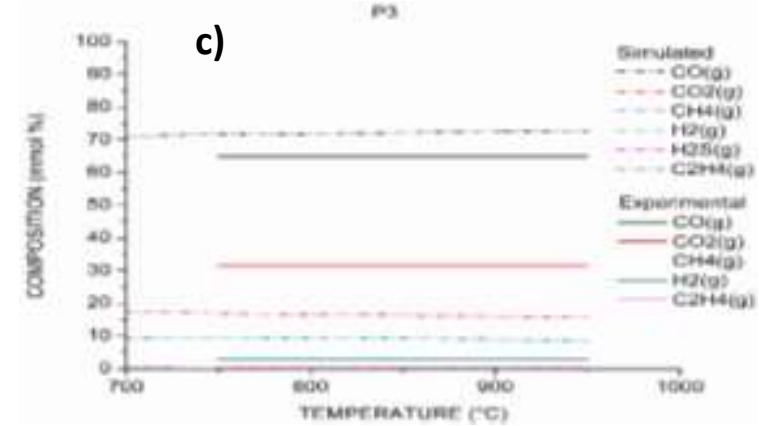

Fig. 6. Curves of simulated and experimental composition for the gasification of a) P1 (Coal), b) P2 (Biomass) and c) P3 (Mixture).

\section{CONCLUSIONS}

The co-processing of coal and Chenopodium album biomass demonstrated physicochemical and environmental synergies. The use of paraffin as a binder for the formation of the combustible mixture does not likely alter the composition of the obtained syngas or modulate the fusibility of the constituent minerals of the ashes in terms of the flux phases.

The composition of the syngas was determined to be dependent on the physicochemical characteristics of the fuel and the process conditions. The syngas obtained from coal had the highest concentration of $\mathrm{H}_{2}$ and the lowest $\mathrm{CO}$. Concentrations of $\mathrm{CH}_{4}, \mathrm{CO}_{2}$ and $\mathrm{C}_{2} \mathrm{H}_{4}$ were similar between coal and biomass. This result is consistent with the higher calorific value of the coal syngas. The production of syngas from the coal-biomass mixture had the highest contents of $\mathrm{H}_{2}$ and $\mathrm{CO}$. This behavior results from the synergistic phenomena that occur with the fuel mixture. The co-gasification of the mixture presents the best values in syngas production, carbon conversion and thermal efficiency. These results indicate the viability of co-gasification with these feedstocks abundant in the Boyacá region (Colombia).

\section{FUNDING}

The article is a product of the research project: "Effect of physicochemical properties of coal-biomass briquettes on the efficiency of the gasification process in a fixed bed", developed through the Research Group "Investigación en Carbones y Carboquímica de la UPTC", research lines: clean technologies, pyrolysis. Financing 
through the scholarship program of the Gobernación de Boyacá through Colciencias. Project approved in Call 733 of 2017 of the Vice-Rector of Investigations of the UPTC, code SGI 2259. Start dates: July 20, 2017. Completion date: December 2018.

\section{ACKNOWLEDGMENTS}

The authors are grateful to Ph.D. Yaneth Pineda Triana from INCITEMA and the Research Group in Carbons and Carboquímica of the UPTC, the Faculty of Mechanical and Electrical Engineering of the Universidad Autónoma de Coahuila en Monclova, México, the Research Group in Energy Efficiency Management of the Universidad del Atlántico (Colombia), and the Energy Sciences Laboratory of the Universidad Nacional de Colombia (Medellín).

This work was authored in part by the National Renewable Energy Laboratory, operated by Alliance for Sustainable Energy, LLC, for the U.S. Department of Energy (DOE) under Contract No. DE-AC36-08GO28308. Funding provided by U.S. Department of Energy Office of Energy Efficiency and Renewable Energy Bioenergy Technologies Office. The views expressed in the article do not necessarily represent the views of the DOE or the U.S. Government. The U.S. Government retains and the publisher, by accepting the article for publication, acknowledges that the U.S. Government retains a nonexclusive, paid-up, irrevocable, worldwide license to publish or reproduce the published form of this work, or allow others to do so, for U.S. Government purposes.

\section{AUTHOR'S CONTRIBUTIONS}

Information about procedures and results from Marco Ardila's doctoral thesis about kinetic model to the coal-biomass briquetes gasification process, and Eduardo Gil's master thesis about briquetes gasification process, is presented; these reserchs were directed by Alfonso López and Fernando Lozano, respectively. The gasification tests in the thermogravimetric analyzer and chromatographic analysis was leaded by Carlos Valdés. The pyrolisis phase analysis and process performance calculations were guided by Brennan Pecha and Marley Vanegas. The 
Marco Antonio Ardila-Barragán, Carlos Francisco Valdés-Rentería, Brennan Pecha, Alfonso López-Díaz,

Eduardo Gil-Lancheros, Marley Cecilia Vanegas-Chamorro, Jesús Emilio Camporredondo-Saucedo, Luis

Fernando Lozano-Gómez

thermodynamic analysis and the equilibrium composition curves were simulated with

HSC software, with Emilio Camporredondo instructions.

\section{REFERENCES}

[1] D. Ayhan, "Sustainable cofiring of biomass with coal," Energy Convers. Manag., vol. 44 (9), pp. 14651479, 2003.

[2] P. Correa, "Colombia Reducirá en un 20\% sus emisiones de CO2," El Espectador, p. 12, Sep. 2015.

[3] A. Demirbaş, "Global renewable energy resources," Energy Sources, Part A Recover. Util. Environ. Eff., vol. 28 (8), pp. 779-792, 2006. https://doi.org/10.1080/00908310600718742.

[4] S. Adhikari, S. Fernando, S. R. Gwaltney, S. D. Filip To, R. M. Bricka, P. H. Steele, and A. Haryanto, "A thermodynamic analysis of hydrogen production by steam reforming of glycerol," Int. J. Hydrogen Energy, vol. 32 (14), pp. 2875-2880, Sep. 2007. https://doi.org/10.1016/i.iihvdene.2007.03.023.

[5] D. Tillman, D. Duong, and N. S. Harding, Solid Fuel Blending: principles, practices and problems. Oxford - Reino Unido: Butterworth-Heinemann, p. 337, 2012.

[6] J. J. Battista Jr., E. E. Hughes, and D. A. Tillman, "Biomass cofiring at Seward Station. (Cofiring benefits for coal and biomass)," Biomass and Bioenergy, vol. 19, pp. 419-427, Dec. 2000. httos://doi.org/10.1016/s0961-9534(00)00053-2.

[7] D. Mallick, P. Mahanta, and V. S. Moholkar, "Co-gasification of coal and biomass blends: Chemistry and engineering," Fuel, vol. 204, pp. 106-128, Sep. 2017. https://doi.org/10.1016/i.fuel.2017.05.006.

[8] J. Rezaiyan, and N. Cheremisinoff, Gasification Technologies: A primer for Engineers and Scientists. Boca Ratón - Florida: VRC Taylor and Francis Group, 2005. https://doi.org/10.1201/9781420028140.

[9] P. N. Sheth, and B. V. Babu, "Experimental studies on producer gas generation from wood waste in a downdraft biomass gasifier," Bioresour. Technol., vol. 100 (12), pp. 3127-3133, 2009. https://doi.org/10.1016/.j.biortech.2009.01.024.

[10] D. A. Bell, B. F. Towler, and M. Fan, Coal Gasification and Its Utilization, vol. I. Elsevier, ButterworthHeinemann, 2011.

[11] L. Emami-Taba, M. F. Irfan, W. M. A. Wan Daud, and M. H. Chakrabarti, "Fuel blending effects on the co-gasification of coal and biomass - A review," Biomass and Bioenergy, vol. 57, pp. 249-263, 2013. https://doi.ora/10.1016/i.biombioe.2013.02.043.

[12] L. . T. Faccini, and D. Nisensohn, Manual de reconocimiento y manejo de malezas. Corpscience Bayer, Rosario - Argentina, p. 100, 2012.

[13] J. Holm, L. Plucknett, D. Pancho, and L. Herberger, The world's worst weeds. Honolulu - Hawaii: University Press, 1977.

[14] M. Coquillat, Sur les plantes les plus communes a la surface du globe. Lyon - France: Société linnéenne de Lyon, pp. 165-170, 1951. https://doi.org/10.3406/linly.1951.7425.

[15] A. Poonia, and A. Upadhayay, "Chenopodium album Linn: review of nutritive value and biological properties," vol. 52, pp. 3977-3985, Jul. 2015. https://doi.org/10.1007/s13197-014-1553-x.

[16] R. Xu, B. Dai, W. Wang, J. Schenk, and Z. Xue, "Effect of iron ore type on the thermal behaviour and kinetics of coal-iron ore briquettes during coking," Fuel Process. Technol., vol. 173, pp. 11-20, Oct. 2018. https://doi.org/10.1016/i.fuproc.2018.01.006.

Revista Facultad de Ingeniería (Rev. Fac. Ing.) Vol. 28 (53), pp. 53-77. Octubre-Diciembre 2019.

Tunja-Boyacá, Colombia. L-ISSN: 0121-1129, e-ISSN: 2357-5328, DOI:

https://doi.org/10.19053/01211129.v28.n53.2019.10147 
[17] G. R. Kale, B. D. Kulkarni, and R. N. Chavan, "Combined gasification of lignite coal: Thermodynamic and application study," J. Taiwan Inst. Chem. Eng., vol. 45 (1), pp. 163-173, 2014. https://doi.org/10.1016/i.jtice.2013.04.015.

[18] C. F. Valdés, G. Marrugo, F. Chejne, J. D. Román, and J. I. Montoya, "Effect of atmosphere reaction and heating rate on the devolatilization of a Colombian sub-bituminous coal," J. Anal. Appl. Pyrolysis, vol. 121, pp. 93-101, 2016. https://doi.org/10.1016/i.jaap.2016.07.007.

[19] R. G. M. Desamparados, Caracterización fundamental de ensayos termogravimétricos - Video. Valencia, España: Universidad Politécnica de Valencia, 2014.

[20] C. F. Valdés, G. Marrugo, F. Chejne, J. I. Montoya, and C. A. Gómez, "Pilot-Scale Fluidized-Bed Cogasification of Palm Kernel Shell with Sub-bituminous Coal," Energy and Fuels, vol. 29 (9), pp. 58945901, 2015. https://doi.org/10.1021/acs.energyfuels.5b01342.

[21] S. V Vassilev, K. Kitano, S. Takeda, and T. Tsurue, "Influence of mineral and chemical-composition of coal ashes on their fusibility," Fuel Process. Technol., vol. 45 (95), pp. 27-51, 1995. https://doi.org/10.1016/0378-3820(95)00032-3.

[22] B. C. Young, M. D. Mann, and M. E. Collings, "Formation of NOx and N2O in the fluidized-bed combustion of high- and low-rank coals," Coal Sci. Technol., vol. 21, pp. 419-436, 1993. https://doi.org/10.1016/b978-0-444-81476-0.50040-5.

[23] K. D. R. Vanderlans, P. Glarborg, "Influence of process parameters on nitrogen oxide formation in pulverized coal burners," Energy Combust., vol. 23, pp. 349-377, 1997. https://doi.org/10.1016/s03601285(97)00012-9.

[24] P. Glarborg, J. A. Miller, B. Ruscic, and S. J. Klippenstein, "Modeling nitrogen chemistry in combustion," Prog. Energy Combust. Sci., vol. 67, pp. 31-68, 2018. https://doi.org/10.1016/i.pecs.2018.01.002.

[25] K. Qin, "Entrained Flow Gasification of Biomass," Doctoral Thesis, Technical University of Denmark, Denmark, pp. 16-39, 2012.

[26] A. Cerquera, C. Rodriguez, and D. Ruano, "Análisis mineralógico, químico y porosimétrico de los agregados pétreos de una cantera perteneciente a la formación geológica de la sabána en el municipio de Soacha-Cundinamarca," Thesis Grade, Universidad Católica de Colombia, Bogotá D.C., Colombia, 2017.

[27] G. Zhang, J. T. Germaine, R. T. Martin, and A. J. Whittle, "A simple sample-mounting method for random powder X-ray diffraction,” Clays Clay Miner., vol. 51 (2), pp. 218-225, 2003. https://doi.org/10.1346/ccmn.2003.0510212.

[28] A. Haryanto, S. D. Fernando, L. O. Pordesimo, and S. Adhikari, "Upgrading of syngas derived from biomass gasification: A thermodynamic analysis," Biomass and Bioenergy, vol. 33 (5), pp. 882-889, 2009. https://doi.org/10.1016/i.biombioe.2009.01.010.

[29] I. N. Levine, Fisicoquímica Vol. 1, Madrid-Spain: Mc Graw Hill, 2004.

[30] K. Kumabe, T. Hanaoka, S. Fujimoto, T. Minowa, and K. Sakanishi, "Co-gasification of woody biomass and coal with air and steam," Fuel, vol. 86 (5-6), pp. 684-689, 2007. https://doi.org/10.1016/i.fuel.2006.08.026.

[31] A. Żogała, "Equilibrium Simulations of Coal Gasification - Factors Affecting Syngas Composition," J. Sustain. Min., vol. 13 (2), pp. 30-38, 2014. https://doi.org/10.7424/ism140205.

[32] R. J. De Armas, D. Macías M., and A. C. Amed A., "Modelamiento y Simulación con Matlab," 2000. Available at: https://es.scribd.com/document/309658623/LIBRO-MODELAMIENTO-Y-SIMULACIONRevista Facultad de Ingeniería (Rev. Fac. Ing.) Vol. 28 (53), pp. 53-77. Octubre-Diciembre 2019. Tunja-Boyacá, Colombia. L-ISSN: 0121-1129, e-ISSN: 2357-5328, DOI: https://doi.org/10.19053/01211129.v28.n53.2019.10147 
Marco Antonio Ardila-Barragán, Carlos Francisco Valdés-Rentería, Brennan Pecha, Alfonso López-Díaz,

Eduardo Gil-Lancheros, Marley Cecilia Vanegas-Chamorro, Jesús Emilio Camporredondo-Saucedo, Luis pdf.

Fernando Lozano-Gómez

[33] M. A. Lara et al., "Thermodynamic simulation of reduction of mixtures of iron ore, siderurgical wastes and coal," Metalurgija, vol. 58 (1), pp. 11-14, 2019.

[34] Z. Ma, D. Chen, J. Gu, B. Bao, and Q. Zhang, "Determination of pyrolysis characteristics and kinetics of palm kernel shell using TGA-FTIR and model-free integral methods," Energy Convers. Manag., vol. 89, pp. 251-259, 2015. https://doi.org/10.1016/i.enconman.2014.09.074.

[35] L. Burhenne, J. Messmer, T. Aicher, and M. P. Laborie, "The effect of the biomass components lignin, cellulose and hemicellulose on TGA and fixed bed pyrolysis," J. Anal. Appl. Pyrolysis, vol. 101, pp. 177184, 2013. https://doi.org/10.1016/j.jaap.2013.01.012.

[36] A. Gani and I. Naruse, "Effect of cellulose and lignin content on pyrolysis and combustion characteristics for several types of biomass," Renew. Energy, vol. 32 (4), pp. 649-661, 2007. https://doi.org/10.1016/j.renene.2006.02.017.

[37] P. R. Solomon, "Coal Structure and Thermal Decomposition. In New Approaches in Coal Chemistry," ACS - Washington, D. C., vol. 169, pp. 61-71, 1981. https://doi.org/10.1021/bk-1981-0169.ch004.

[38] A. Molina, and C. R. Shaddix, "Ignition and devolatilization of pulverized bituminous coal particles during oxygen/carbon dioxide coal combustion," Proc. Combust. Inst., vol. 31, pp. 1905-1912, 2007. https://doi.org/10.1016/i.proci.2006.08.102.

[39] J. F. Vélez, F. Chejne, C. F. Valdés, E. J. Emery, and C. A. Londoño, "Co-gasification of Colombian coal and biomass in fluidized bed: An experimental study," Fuel, vol. 88 (3), pp. 424-430, 2009. https://doi.org/10.1016/i.fuel.2008.10.018.

[40] M. S. Masnadi-Shirazi, "Biomass/fossil fuel co-gasification with and without integrated CO2 capture," Doctoral Thesis, University of British Columbia, Vancouver, Canada, 2014.

[41] G. Marrugo, C. F. Valdés, and F. Chejne, "Characterization of Colombian Agroindustrial Biomass Residues as Energy Resources," Energy and Fuels, vol. 30 (10), pp. 8386-8398, 2016. https://doi.org/10.1021/acs.enerqyfuels.6b01596.

[42] M. Wang, L., Hustad, J.E., Skreiberg, Ø., Skjevrak, and G., Grønli, "A Critical Review on Additives to Reduce Ash Related Operation Problems in Biomass Combustion Applications.," Energy Procedia, vol. 20, pp. 20-29, 2012. https://doi.org/10.1016/i.eqvpro.2012.03.004.

[43] T. C. Drage, C. H. Vane, and G. D. Abbott, "The closed system pyrolysis of $\beta-O-4$ lignin substructure model compounds," Org. Geochem., vol. 33 (12), pp. 1523-1531, 2002. https://doi.org/10.1016/s0146$\underline{6380(02) 00119-5}$.

[44] P. R. Solomon, D. G. Hamblen, R. M. Carangelo, M. A. Serio, and G. V. Deshpande, "General model of coal devolatilization," Energy \& Fuels, vol. 2, pp. 405-422, May. 2002. https://doi.org/10.1021/ef00010a006.

[45] G. Marrugo, "Efecto de los cambios estructurales de diferentes biomasas pirolizadas sobre las características del gas de síntesis, obtenido a partir de la gasificación de biochar," Master Thesis, Universidad Nacional de Colombia, Bogotá D.C., Colombia, 2015.

[46] C. L. Lin, and W. C. Weng, "Effects of different operating parameters on the syngas composition in a two-stage gasification process," Renew. Energy, vol. 109, pp. 135-143, 2017. https://doi.org/10.1016/..renene.2017.03.019.

[47] O. A. Oyelaran, F. M. Sani, O. M. Sanusi, O. Balogun, and A. O. Fagbemigun, "Energy Potentials of 
Gasification of coal, Chenopodium Album biomass, and co-gasification of a coal-biomass mixture by thermogravimetric-gas analysis

Briquette Produced from Tannery Solid Waste," Makara J. Technol., vol. 21 (3), p. 122, 2018. https://doi.org/10.7454/mst.v21i3.3429.

[48] A. A. Bhuiyan, A. S. Blicblau, A. K. M. S. Islam, and J. Naser, "A review on thermo-chemical characteristics of coal/biomass co-firing in industrial furnace," J. Energy Inst., vol. 91 (1), pp. 1-18, 2018. https://doi.org/10.1016/i.joei.2016.10.006.

[49] P. Glarborg, "Fuel nitrogen conversion in solid fuel fired systems," Energy Combust, vol. 29, pp. 89-113, 2003. https://doi.org/10.1016/s0360-1285(02)00031-x.

[50] C. F. Valdés, F. Chejne, G. Marrugo, R. J. Macias, C. A. Gómez, J. I. Montoya, C. A.Londoño, J. De La Cruz, and E. Arenas, "Co-gasification of sub-bituminous coal with palm kernel shell in fluidized bed coupled to a ceramic industry process," Appl. Therm. Eng., vol. 107, pp. 1201-1209, 2016. https://doi.ora/10.1016/i.applthermaleng.2016.07.086.

[51] S. Usón, A. Valero, L. Correas, and Á. Martínez, "Co-gasification of coal and biomass in an IGCC power plant: Gasifier modeling," Int. J. Thermodyn., vol. 7 (4), pp. 165-172, 2004.

[52] M.R. Riazi; and R. Gupta, Coal production and processing technology. Boca Raton-Florida: CRC Press, 2016.

[53] Y. Ninomiya, and A. Sato, "Ash melting behavior under coal gasification conditions," Energy convers, vol. 38 (10), pp. 1405-1412, 1997. https://doi.org/10.1016/s0196-8904(96)00170-7.

[54] X. Wu, Z. Zhang, G. Piao, X. He, Y. Chen, N. Kobayashi, S. Mori, and Y. Itaya, "Behavior of mineral matters in chinese coal ash melting during char- $\mathrm{CO} 2 / \mathrm{H} 2 \mathrm{O}$ gasification reaction," Energy and Fuels, vol. 23 (5), pp. 2420-2428, 2009. https://doi.org/10.1021/ef801002n.

[55] X. Wu, Z. Zhang, Y. Chen, T. Zhou, J. Fan, G. Piao, N. Kobayashi, S. Mori, and Y.Itaya, "Main mineral melting behavior and mineral reaction mechanism at molecular level of blended coal ash under gasification condition," Fuel Process. Technol., vol. 91 (11), pp. 1591-1600, 2010. https://doi.org/10.1016/i.fuproc.2010.06.007.

[56] L. L. Baxter, L.L., Miles, T.R., Miles, T.R., Jenkins, B.M., Milne, T., Dayton, D., Bryers, R.W., Oden, "The behavior of inorganic material in biomass-fired power boilers: field and laboratory experiences.," Fuel Process, vol. 5, pp. 47-78, 1998. https://doi.org/10.2172/251289.

[57] P. Johansen, J.M. Aho, M. Paakkinen, K. Taipale, R. Egsgaard, H. Jakobsen, J.G. Frandsen, and F.J. Glarborg, "Release of $\mathrm{K}, \mathrm{Cl}$, and $\mathrm{S}$ during combustion and co-combustion with wood of high-chlorine biomass in bench and pilot scale fuel beds," Release $\mathrm{K}, \mathrm{Cl}$, S Dur. Combust. co-combustion with wood high-chlorine biomass bench Pilot scale fuel beds., vol. Proc. Comb, pp. 2363-2372, 2013. httos://doi.org/10.1016/i.proci.2012.07.025.

[58] Z. Werther, J., Saenger, M., Hartge, E.-U., Ogada, T., Siagi, "Combustion of agricultural residues.," Energy Combust., vol. 26, pp. 1-27, 2000. https://doi.org/10.1016/s0360-1285(99)00005-2. 